FEDERAL RESERVE BANK OF SAN FRANCISCO

WORKING PAPER SERIES

\title{
Currency Crises, Capital Account Liberalization, and Selection Bias
}

\author{
Reuven Glick \\ Federal Reserve Bank of San Francisco \\ Xueyan Guo \\ University of California, Santa Cruz \\ and \\ Michael Hutchison \\ University of California, Santa Cruz
}

Working Paper 2004-15

http://www.frbsf.org/publications/economics/papers/2004/wp04-15bk.pdf

The views in this paper are solely the responsibility of the authors and should not be interpreted as reflecting the views of the Federal Reserve Bank of San Francisco or the Board of Governors of the Federal Reserve System. This paper was produced under the auspices for the Center for Pacific Basin Studies within the Economic Research Department of the Federal Reserve Bank of San Francisco. 


\title{
Currency Crises, Capital Account Liberalization, and Selection Bias
}

\author{
Reuven Glick \\ Federal Reserve Bank of San Francisco \\ Email: reuven.glick@sf.frb.org \\ Xueyan Guo \\ University of California, Santa Cruz \\ Email: xguo@ucsc.edu \\ Michael Hutchison \\ University of California, Santa Cruz \\ Email: hutch@ucsc.edu
}

First Draft: June 2004

Current Draft: June 30, 2005

\begin{abstract}
Are countries with unregulated capital flows more vulnerable to currency crises? Efforts to answer this question properly must control for "self selection” bias since countries with liberalized capital accounts may also have more sound economic policies and institutions that make them less likely to experience crises. We employ a matching and propensity score methodology to address this issue in a panel analysis of developing countries. Our results suggest that, after controlling for sample selection bias, countries with liberalized capital accounts experience a lower likelihood of currency crises. That is, when two countries have the same likelihood of allowing free movement of capital (based on historical evidence and a very similar set of economic and political characteristics) - and one country imposes controls and the other does not-- the country without controls has a lower likelihood of experiencing a currency crisis.
\end{abstract}

The views presented in this paper are those of the authors alone and do not necessarily reflect those of the Federal Reserve Bank of San Francisco or the Board of Governors of the Federal Reserve System. We thank Rick Mishkin, participants at the Federal Reserve Bank of New York conference on Global Finance, participants at seminars at Claremont McKenna College, the University of California at Santa Cruz, and the University of Hawaii, and two anonymous referees for helpful comments. Please address correspondence to Hutchison at hutch@ucsc.edu. 


\section{Introduction}

The benefits and costs of liberalizing administrative and legal controls on international capital flows have been the subject of renewed debate in recent years. Some studies suggest that eliminating or reducing the extent of these types of controls and restrictions can lower the cost of capital, promote portfolio diversification and risk sharing, and/or reduce microeconomic distortions, thereby improving investment, productivity, and growth. ${ }^{1}$ Nonetheless, supporters of capital controls argue that they can yield benefits by reducing country vulnerability to volatile capital flows and currency crises. Recent examples of emerging markets that liberalized their capital accounts and subsequently experienced currency crises in the 1990s are often cited to support this view. For example, the crises of Mexico (1994-95) and of Asia (1997-98) are often attributed to premature liberalization of international capital flows. ${ }^{2}$

While there is an extensive empirical literature measuring the effects of capital account liberalization on particular economic variables-e.g. capital flows, interest differentials, inflation, and output—surprisingly little systemic work has been undertaken regarding its impact on exchange rate stability in developing countries. Several papers have investigated the relationship of exchange rates and capital controls and/or capital account liberalization for a few selected countries (e.g. Edison and Reinhart, 2001a, 2001b; Edwards, 1999; Gregorio et al, 2000), while Glick and Hutchison (2005) have done so for a broad set of developing and emerging market economies.

In general, these studies find little effect of capital controls in averting currency crises, at least not without supporting economic policies. They typically have found capital controls to be ineffective, distortionary, and/or counterproductive in the sense of signaling inconsistent and poorly designed government policies that may induce capital flight (see Bartolini and Drazen, 1997a). Glick and Hutchison (2005) in fact find a significant positive correlation between capital controls and the occurrence of currency crises. Specific examples supporting these findings are commonplace-Malaysia experienced a currency crisis in late 1997, despite having re-imposed capital controls a year earlier; El Salvador experienced crises in 1986 and again in 1990 despite having controls, while not having a crisis when controls were liberalized in 1996-97; Kenya has

\footnotetext{
${ }^{1}$ While there is agreement that capital market integration is qualitatively beneficial over the long run, there is much debate about the magnitude of these benefits; e.g., see Gourinchas and Jeanne (2003).

${ }^{2}$ The appropriate pace of deregulation of domestic financial markets also has been of concern, even in many industrial countries. The United States, Japan, and Sweden, among others, all have experienced some domestic financial instability following deregulation of domestic financial institutions.
} 
had six currency crises since 1975 despite having controls over most of this period; and so on. Dooley (1996), summarizing the literature, concludes: “Capital controls or dual exchange rate systems have been effective in generating yield differentials, covered for exchange rate risk, for short periods of time, but they have little power to stop speculative attacks on regimes that were seen by the market as inconsistent” (p. 677).

One possible explanation of why capital controls may be associated, not with a lower vulnerability, but in fact with a greater vulnerability to currency crises concerns the special characteristics and "self selection" of countries that choose to liberalize their capital accounts. Countries with macroeconomic imbalances, financial weaknesses, political instability, and/or institutional problems may choose to retain capital controls in order to avoid difficult economic reforms or to avoid capital outflows that may trigger a crisis. Conversely, countries with sound macroeconomic and political environments and more robust financial systems and institutions are not only less likely to experience crises, but also may be less likely to enact capital controls and forego the benefits of free capital flows. Consequently, countries with open capital accounts may be less prone to financial crises, both domestic and international in origin. Although capital controls may reduce country vulnerability to crises in some cases, capital account liberalization can still be associated with a lower overall likelihood of financial crises.

A particular source of concern for empirical analysis arises when the policy choice to establish or maintain an environment with a liberalized capital account is correlated with macroeconomic, financial, and institutional policy variables that in turn lower the likelihood of currency crises. Specifically, estimation of the likelihood of crises may yield a biased measure of the effect of capital controls because of sample selection bias, i.e., systematic differences between countries that do and do not liberalize the capital account. ${ }^{3}$ In light of possible sample selection bias for the group of countries that maintain a liberalized capital account-- and the fact that studies to date have not dealt with this issue -- can we put much faith in prior empirical findings that free movement of capital reduces a country’s vulnerability to currency crises?

In this paper we address the sample selection problem by employing the matching and propensity score methodology that was developed precisely for the bias associated with this type

\footnotetext{
${ }^{3}$ Glick and Hutchison (2005) control for a host of economic, political, and institutional factors usually associated with currency instability and capital controls. They also develop an empirical model of the factors explaining governments' decisions to maintain capital controls, jointly explaining this decision with the onset of currency attacks through bivariate probit estimation. However, they do not formally address the issue of sample selection bias.
} 
of estimation problem. In particular, we apply the matching methodology developed to help account for the estimation bias arising from the "selection on observables" problem, which to date has mainly been applied in the medical and labor economics literature. ${ }^{4}$ The basic idea is straightforward. Each participation observation is matched to a non-participation observation that has the same observed values of a vector of other characteristics that determine participation. Under certain standard assumptions, the difference in the observed outcome between the two matched observations is thus the program's effect. As Heckman et al. (1997) state: “...simple balancing of observables in the participant and comparison group samples goes a long way toward producing a more effective evaluation strategy” (p. 607).

This paper evaluates the effect of an environment with liberalized capital flows on the likelihood of currency crises using several recently developed matching methods designed to deal with sample selection bias. In particular, we use "nearest neighbor”, "radius,” and "stratification" matching methods -- all methods designed to account for selection on observables bias. As a robustness check, we also estimate a probit equation of currency crises for samples of matched observations to investigate the effect of liberalization after controlling for other factors.

Our analysis suggests that, even after controlling for sample selection bias (and obtaining unbiased estimates), a liberalized capital account is associated with a lower likelihood of currency crises. That is, when two countries have the same likelihood of allowing free movement of capital (based on historical evidence and a very similar set of identical economic and institutional characteristics at a point in time) — and one country imposes controls and the other does not-- the country without controls has a lower likelihood of experiencing a currency crisis. The strength of this finding varies in robustness checks, but a lower likelihood is always evident.

The plan of the paper is as follows. Section 2 discusses the matching methodology in more detail and its application to the problem at hand. Section 3 discusses construction of the key variables in our analysis - measures of currency crises and of capital account liberalization and gives descriptive statistics. Section 4 presents empirical results concerning calculation of the propensity scores used in creating the matched samples. Section 5 presents the main results of

\footnotetext{
${ }^{4}$ The selection bias problem typically addressed in the medical and health care literature arises when the patients with worse health problems seek out the better doctors and facilities. In assessing treatment effectiveness, matching methods are employed to control for the downward bias associated with the lower survival rates of these patients. Persson (2001) and Hutchison (2004) are exceptions in the macroeconomics literature by applying the matching methodology to investigations of, respectively, the effect of currency unions on trade growth and the effect of IMF program participation on output growth.
} 
the paper measuring the effect of capital account liberalization on currency crises while controlling for selection bias. We also consider various robustness exercises. Section 6 discusses explanations for our findings and concludes the paper.

\section{Matching Methodology}

The advantage of matching methods is that they address the problem of non-random sample selection and, as a non-parametric statistical method, avoid strong assumptions about functional form ${ }^{5}$. To examine the effect of capital account liberalization on the occurrence of currency crises we employ three matching algorithms — nearest neighbor, stratification, and radius matching-These different approaches all match observations with similar characteristics, excepting that one group of countries liberalizes capital controls (the "treatment group”) and the other does not (the "control group”). Following the matching of observations, we assess the "treatment effect" by measuring the difference in the frequency of currency crises between the two groups.

In order to assess similarity among countries and construct the samples of countries with and without liberalized capital accounts (the "participation” and "non-participation” observations, respectively), we consider a set of observable country characteristics. One approach is to match each participation observation with a non-participation observation that has exactly the same observed values of a vector of other characteristics that determine participation $(X)$. In macroeconomic studies, where the size of the sample is typically limited, this matching method is difficult or impossible to implement. Fortunately, Rosenbaum and Rubin (1983 and 1985) have shown that, if the probability of participation - $P(X)$ - is known, then matching by $P(X)$ instead of $X$ is sufficient. This collapses the multidimensional problem of matching to one dimension based on the estimated probabilities or propensity scores and greatly simplifies the procedure. Rubin and Thomas (1992) show that using an estimated probability of participation $\tilde{P}(X)$ based on the set of observable characteristics, instead of $P(X)$, still reduces selection-onobservables bias. When two countries have a similar propensity score, they are paired according to one of the following three matching criteria.

The nearest neighbor approach matches each participation observation to the nonparticipation observation that has the nearest propensity score. After each non-participation

\footnotetext{
${ }^{5}$ See Persson (2001) for an excellent review of matching methodology and an application with macroeconomic data.
} 
observation is used, it is "returned" to the pool of non-participation observations. The treatment effect is computed as a simple average of the differences in outcomes across the paired matches. The radius approach matches each participation observation to the average of all the nonparticipation observations with propensity scores falling within a pre-specified radius from the propensity score of the participation observation ${ }^{6}$. In this case, the treatment effect is again computed as an average of the difference in outcomes, but with weighting according to the number of non-participation observations used in the construction of each matched pair. The stratification approach divides the sample into several groups, or strata, based on their propensity scores. Within each stratum, the average of the participation observations is matched with the average of the non-participation observations. An average of the difference in outcomes of the strata, weighted by the number of participation observations in each one, is then calculated to create the treatment effect. In all three cases, weighted standard errors are constructed as described in the appendix of Persson (2001). ${ }^{7}$

\section{Data Construction and Descriptive Statistics}

\section{3a. Defining Currency Crises}

The objective of this study is to evaluate the effect of capital account liberalization on the incidence of currency crises for a panel of developing countries. ${ }^{8}$ We include developing countries that both did and did not experience a severe currency crisis/speculative attack during the 1975-97 sample period. Using such a broad control group allows us to make inferences about the conditions and characteristics distinguishing countries encountering crises and others managing to avoid crises. The minimum data requirements to be included in our study are that GDP are available for a minimum of 10 consecutive years over the period 1975-97. This requirement results in a sample of 69 developing countries.

To identify currency crises we construct a measure of monthly exchange rate pressure and date each by the year in which it occurs. Specifically, currency crises are defined as "large"

\footnotetext{
${ }^{6}$ More specifically, for radius of magnitude $r$, each participation observation with an estimated propensity score $\tilde{n}$ is matched with all the non-participation observations whose propensity scores $(q)$ satisfy the condition $\tilde{n}-r<q<\tilde{n}+r$. We use a value of $r=.005$ as our benchmark value.

${ }^{7}$ The nearest neighbor and radius approaches are each implemented in Dehejia and Wahba (2002), who also employ a version of the stratification method to estimate propensity scores. All three methods are implemented in Persson (2001).

${ }^{8}$ We include industrial countries in the sample as a robustness exercise later in the paper.
} 
changes in a monthly index of currency pressure, measured as a weighted average of monthly real exchange rate changes ${ }^{9}$ and monthly (percent) reserve losses. ${ }^{10}$ Following convention (e.g. Kaminsky and Reinhart, 1999), the weights attached to the exchange rate and reservation components of the currency pressure index are inversely related to the variance of changes of each component over the sample for each country. ${ }^{11}$ The exchange rate and reserve data are drawn from the International Monetary Fund's International Financial Statistics CD-ROM (lines ae and 11.d, respectively).

Our measure presumes that any nominal currency changes associated with the exchange rate pressure should affect the purchasing power of the domestic currency, i.e. result in a change in the real exchange rate (at least in the short run). This condition excludes some large depreciations that occur during high inflation episodes, but it avoids screening out sizable depreciation events in more moderate inflation periods for countries that have occasionally experienced periods of hyperinflation and extreme devaluation. ${ }^{12}$ Large changes in exchange rate pressure are defined as changes in our pressure index that exceed the mean plus 2 times the country-specific standard deviation, provided that it also exceeds 5 percent. ${ }^{13}$ The first condition insures that any large (real) depreciation is counted as a currency crisis, while the second condition attempts to screen out changes that are insufficiently large in an economic sense relative to the country-specific monthly change of the exchange rate.

\footnotetext{
${ }^{9}$ Real exchange rate changes are defined in terms of the trade-weighted sum of bilateral real exchange rates (constructed in terms of CPI indices, line 64 of the IFS) against the U.S. dollar, the German mark, and the Japanese yen, where the trade-weights are based on the average of bilateral trade with the United States, the European Union, and Japan in 1980 and 1990 (from the IMF's Direction of Trade). Most panel studies of currency crises define the currency pressure measure in terms of the bilateral exchange rate against a single foreign currency. For example, Kaminsky, Lizondo, and Reinhart (1998) and Kaminsky and Reinhart (1999) measure the real exchange rate for all of the developing countries in their sample against the U.S. dollar. In defining the effective rate in terms of the three major nations likely to be main trading partners of most developing countries, our approach provides a broader measure than these other studies and is computationally easier to construct than a multilateral exchange rate measure defined in terms of all of a country's trading partners.

${ }^{10}$ Ideally, reserve changes should be scaled by the level of the monetary base or some other money aggregate, but such data is not generally available on a monthly basis for most countries.

${ }^{11}$ Our currency pressure measure of crises does not include episodes of defense involving sharp rises in interest rates. Data for market-determined interest rates are not available for much of the sample period in many of the developing countries in our dataset.

${ }^{12}$ This approach differs from that of Kaminsky and Reinhart (1999), for example, who deal with episodes of hyperinflation by separating the nominal exchange rate depreciation observations for each country according to whether or not inflation in the previous 6 months was greater than 150 percent, and they calculate for each subsample separate standard deviation and mean estimates with which to define exchange rate crisis episodes.

${ }^{13}$ Kaminsky and Reinhart (1999) use a three standard deviation cut-off. While the choice of cut-off point is somewhat arbitrary, Frankel and Rose (1996) suggest that the results are not very sensitive to the precise cut-off chosen in selecting crisis episodes.
} 
For each country-year in our sample, we construct a binary measure of currency crises, as defined above ( 1 = crisis, $0=$ no crisis). A currency crisis is deemed to have occurred for a given year if the change in currency pressure for any month of that year satisfies our criteria (i.e. two standard deviations above the mean as well as greater than five percent in magnitude). To reduce the chances of capturing the continuation of the same currency crisis episode, we impose windows on our data. In particular, after identifying each "large" monthly change in currency pressure, we treat any large changes in the following 24-month window as part of the same currency episode and skip the years of that change before continuing the identification of new crises. With this methodology, we identify 160 currency crises over the 1975-97 period. Appendix C lists the countries included in the sample and corresponding currency crisis dates, if any.

\section{3b. Measuring Liberalization of Restrictions on International Payments}

The underlying source for our measures of capital account liberalization are data on external restrictions in the IMF's Annual Report on Exchange Arrangements and Exchange Restrictions (EAER). A country is classified as either "liberalized (value of unity) or "restricted (value of zero) depending on the existence of controls on the capital account at year-end. Specifically, for the 1975-94 period the EAER coded countries (published in the reports through 1995) for the existence (or not) of "restrictions on payments for capital transactions.” From 1996, the EAER (starting with the 1997 Annual Report) reported 10 separate categories for controls on capital transactions (11 categories in the 1998 Annual Report). We defined the capital account to be restricted for the 1996-97 observations (i.e. not liberalized) if controls were in place in 5 or more of the EAER sub-categories of capital account restrictions and "financial credit" was one of the categories restricted. ${ }^{14}$

We are aware of concerns about the quality of the IMF data on capital account liberalization. By providing only a dichotomous indication of the existence of administrative controls, they are limited in their ability to measure the extent to which restrictions are applied and enforced over time and across countries. Nor do they clearly distinguish between restrictions

\footnotetext{
${ }^{14}$ The 11 classifications under capital restrictions reported in the 1998 EAER were controls on: (1) capital market securities, (2) money market instruments, (3) collective investment securities, (4) derivatives and other instruments, (5) commercial credits, (6) financial credits, (7) guarantees, sureties, and financial backup facilities, (8) direct investment, (9) liquidation of direct investment, (10) real estate transactions, and (11) personal capital movements.
} 
on capital inflows and outflows. However, the IMF measures are the only source of data available that can be collected with some consistency across a broad group of developing countries and over a reasonably long period of time. This is a constraint faced by any panel study in this literature. ${ }^{15}$ Glick and Hutchison (2005) consider alternative balance of payment restriction indicators, including controls on export receipts or current account transactions, as well as domestic financial controls. They find that while these alternative measures differ somewhat in indicating the presence of controls for individual countries, their results were not sensitive to the particular measure used: countries without restrictions, however measured, were always less prone to currency crises.

\section{3c. Descriptive Statistics on Currency Crises and Capital Account Liberalization}

Table 1 shows the frequency of country-years with currency crises and capital account liberalization over the 1975-97 period, and by 5-year intervals (except for the 1995-97 subsample). The table reports the unconditional frequency of currency crises and liberalization observations (i.e., the number of "crisis" or "liberalization in place” observations, divided by the total number of observations).

The 69 developing countries in our dataset experienced 160 currency crises over the 1975-97 period, implying a frequency of 11.7 percent of the available country-year observations. Crises were least frequent during the 1975-79 period (9.9 percent average frequency) and most frequent during the 1985-89 period (14.3 percent frequency). The frequency of crises in the most period of our sample, 1995-97, was only 9.7 percent. Thus, in our sample, the spate of currency crises around the world in the latter half of the 1990s does not indicate a rise in the frequency of currency crises over time. ${ }^{16}$

Table 1 also reports the frequency with which liberalized capital accounts were in place during the period. Liberalized capital flows were relatively infrequent, accounting for only 16.2 percent of the observations. Although this frequency was always low during the sample period, it fell noticeably from 1975 through 1989, before rising $n$ the 1990s. The low point was an average frequency of 11.0 percent during 1985-89, and the high point was 23.8 percent during 1995-97.

\footnotetext{
${ }^{15}$ See Edison et al (2002) for a comparison of different measures of capital controls in the context of an analysis of the effects of capital account liberalization on long-run economic growth.

${ }^{16}$ Currency crises were most frequent in Africa (16.2 percent frequency), and least frequent in Asia (9.6 percent). Despite recent high profile currency crises in Thailand, Malaysia, Indonesia, and Korea, the developing economies in Asia have been less frequently affected by currency instability.
} 


\section{3d. Currency Crisis Frequencies Conditional on Capital Account Liberalization}

Table 2 shows the frequency of currency crises conditional upon a country's having liberalized capital flows. This table sheds light directly upon the main question of interest: whether liberalization of capital flows affects the probability of a currency crisis. To take account of the possibility that controls are implemented in response to a crisis, we report results conditional on the absence of controls at the end of the year prior to a crisis as well as at the end of the year in which a crisis occurs. $\chi^{2}$ statistics for tests of the null hypothesis of independence between the frequency of crises and whether liberalization was in place are also presented.

The most striking result from Table 2 is that the country-year observations associated with less restrictions on capital flows have substantially lower frequencies of currency crises than those observations where controls were in place. Specifically, countries with liberalized capital flows had crises contemporaneously 6.8 percent of the time, compared to 12.7 percent for those with restrictions. The $\chi^{2}$ statistics reject the null of independence and indicate that this difference is significant (at better than 5 percent). The difference in currency crisis frequency according to whether the capital account was liberalized or not in the preceding year is smaller (8.0 percent versus 12.5 percent), but is still significant at the 10 percent level. This is suggestive prima facie evidence that controls may not be effective and, indeed, may increase the likelihood of a currency crisis. It suggests that the presence of capital controls does not reduce a country's exposure to currency instability.

\section{Preliminaries: Estimating Propensity Score and Currency Crisis Equations}

\section{4a. Propensity Scores}

In controlling for sample selection bias, a benchmark probit equation explaining the likelihood of a country having a liberalized capital account is estimated to calculate propensity scores. We consider a number of potential structural, political, and economic determinants of capital account liberalization. The selection of these potential variables is guided by previous literature in this area. Alesina, Grilli, Milesi-Ferretti (1994), Bartolini and Drazen, (1997a, b), Glick and Hutchison (2005) and Grilli and Milesi-Ferretti (1995), for example, present empirical results on a number of possible determinants of capital controls (and/or capital account liberalization). They find countries with a higher level of government expenditure, more closed 
to international trade, and with larger current account deficits are more likely to restrict capital flows. Grilli and Milesi-Ferretti (1995) also report evidence that more frequent changes in government are associated with fewer capital account restrictions in developing economies. Bartolini and Drazen (1997b) link a high degree of restrictions on international payments in developing economies with high world real interest rates-measured as the weighted real interest rate in the G-7 industrial countries - in a yearly time-series regression. They view the causality as running from world interest rates to capital flow restrictions: restrictions are removed when the cost of doing so is low, i.e. only a small outflow of capital is expected when world interest are low. Edwards (1989), investigating the experiences of twenty countries over the 1961-82 period, finds that capital controls are frequently intensified in the year prior to the onset of a currency crisis. This suggests that a common set of factors may contribute both to the onset of a currency crisis and lead governments to impose or maintain capital account restrictions, or conversely liberalize their capital accounts.

Following these studies, we include two macroeconomic variables, two economic structure variables, and a political variable in our benchmark probit selection equation. The macroeconomic variables are the current account (as a percent of GDP) and the level of “Northern” real interest rates (proxied by the level of the U.S. real long-term interest rate). The economic structure factors considered are the relative size of government spending and openness to world trade (measured by the sum of exports and imports as a percentage of GDP). These macroeconomic data series are taken from the International Monetary Fund's International Finance Statistics (IFS) CD-ROM. The political explanatory variable included in our model is the total number of changes in government. For developing countries, infrequent changes in government may be interpreted as a proxy for persistent and monolithic rule with limited incentives for reform. ${ }^{17}$

The set of variables in our benchmark specification for the selection equation is limited, but these variables are generally available for a wide set of developing countries. Moreover, as we show below, it provides a balance of characteristics between the resulting treatment and matched comparison groups that is desirable for the effectiveness of our treatment evaluation

\footnotetext{
${ }^{17}$ The total number of democratic and undemocratic (e.g. coups) changes in government over the period 1970-97 was determined from Zarate's Political Collections website (www.terra.es/personal2/monolith), supplemented by information from the Encarta Encyclopedia website (www.encarta.msn.com). For our sample of countries, the number of coups is relatively infrequent. Grilli and Milesi-Ferretti (1995) employ a similar measure.
} 
strategy. In robustness exercises we also estimate augmented probit selection equations with additional variables. These additional variables include measures of financial development and institutional quality, which have been shown to play an important role in economic performance. $^{18}$ However, augmenting the set of explanatory variables comes at the cost of reduced sample size.

The financial development variables are the private credit/GDP ratio and a proxy for financial repression. Higher levels of private credit, ceteris paribus, may be interpreted as indicator of greater financial depth and hence of financial development. The financial repression variable is defined in terms of the real interest rate, with higher values associated with more negative real interest rates and interpreted as indicating more financial repression in the economy. ${ }^{19}$ It is expected that the likelihood of pursuing capital account liberalization rises with financial development and declines with financial repression. Our institutional quality variable is an overall index of the quality of governance, corruption, the rule of law, risk of expropriation, and the repudiation of contracts. ${ }^{20}$ We expect that greater institutional quality is associated with greater flexibility in response to economic shocks and hence a greater likelihood that capital account liberalization is implemented.

Appendix A, column (1) presents our benchmark probit model used to predict the likelihood of capital account liberalization. In this specification, larger current account

\footnotetext{
${ }^{18}$ For example, see Mauro (1995), Easterly and Levine (2003) and IMF (2003).

${ }^{19}$ Demirguc-Kunt and Levine (2001) use the private credit/GDP ratio as an indicator of financial development; it is defined as line 32d over 99b, as drawn from the IMF IFS CD-ROM. (2001). Following Roubini and Sala-i-Martin (1992), the financial repression measure is defined as a discrete variable that takes the value of 1 when the average of the real interest rate over the current and previous four years is positive, two when it is negative but higher than minus $5 \%$, and 3 when lower than minus $5 \%$. The real interest rate is defined as the money market rate or, alternatively, the discount rate for the year minus the ex post CPI inflation rate over the past year (IFS line 60 or $60 \mathrm{~b}$ minus the percent change in line 64).

${ }^{20}$ The institutional quality variable comes from Easterly and Levine (1997) who use data from Knack and Keefer (1995) who constructed an aggregate index from separate indicators of bureaucratic quality, government corruption, the rule of law, expropriation risk, and the repudiation of contracts by government, based on surveys by the International Country Risk Guide (ICRG) for the period 1980-89. This index is defined on a 0-6 scale with higher values indicating greater institutional quality. The data were downloaded from the website http://www.worldbank.org/research/growth/ddeale.htm.

Other measures of institutional quality and corruption were considered as well, including the aggregate governance measures of Kaufmann, Kraay, and Zoido-Lobaton (KKZ, 1999a, b) indicators and property rights protection measure from the Heritage Foundation - all used in IMF (2003), and the corruption index of Mauro (1995). Unfortunately these variables were typically available only for years towards the end of our sample, e.g. the KKZ measures are available only for years 1996 and later; or only for a limited set of countries, e.g , the Mauro (1995) corruption index is available for only 38 of the 69 countries in our sample, while the Knack and Keefer measure we use was available for 60 countries.

We also considered nonlinear forms of our specifications by adding square terms involving some of our explanatory variables, but none proved significant.
} 
surpluses, greater trade openness, higher world interest rates, and more frequent changes in government are all associated with a higher likelihood that capital account liberalization is in place. Higher levels of government spending are associated with a lower likelihood of liberalization. All coefficient signs are statistically significant and consistent with priors, with the exception of the interest rate, which is not significant. ${ }^{21}$

In our benchmark probit specification, the observations with a liberalized capital account are predicted correctly $62 \%$ of the time, while those with capital controls are predicted correctly $52 \%$ of the time. (We use the unconditional frequency of capital account liberalization, 16.2\%, as our cutoff for correct predictions reported for the full sample in Table 1.)

Columns (2), (3), and (4) of Appendix A report the augmented specification with combinations of our measures of financial development and institutional quality included as explanatory variables in the probit model. The private credit/GDP ratio by itself (see col. 2) has a positive effect on the likelihood of capital account liberalization, at almost a 10\% significant level, as expected. Greater financial repression (col. 3) has a negative effect on the likelihood of capital control liberalization, also as expected. However, the inclusion of the financial repression variable reverses the sign of the credit variable. Evidently, the degree of financial repression adequately controls for the level of financial development, so that the negative sign on the private credit ratio might then be reflecting high credit growth associated with overly expansionary lending that is inconsistent with liberalization. When institutional quality is added as well (col. 4), it has the expected positive sign and is significant at better than 1 percent; the signs of both financial development variables remain negative (though the significance of the repression variable drops).

The augmented probit predicts marginally better than the benchmark specification, correctly calling $67 \%$ of the liberalization and $60 \%$ of the capital controls correctly. Correspondingly, the pseudo-R2 of the augmented models is somewhat higher (0.43, compared to 0.37 for the benchmark model). Note that limited data in developing countries for interest rates used in constructing the financial repression measure explains most of the reduction in the sample size from 1219 observations in the benchmark case in column (1) to 867 and 736

\footnotetext{
${ }^{21}$ The test statistics of significance are based on bootstrapped standard errors. We note that Grilli and Milesi-Ferretti (1995) get a similar result for the effects of political stability as measured by the frequency of government change on the likelihood of capital account controls for developing countries.
} 
observations, respectively, for the augmented specifications in columns (3) and (4) of Appendix A.

Table 3 shows summary statistics (mean values and standard errors) for economic and political variables in the treatment group (171 country-year observations with capital account liberalization in place) and the unmatched control group (881 observations with capital controls). We also present summary statistics for two alternative control groups-observations matched (using propensity scores derived from the probit equation explaining capital controls) by either the nearest neighbor method or the radius measure (with a radius magnitude of 0.005 ). In addition, we report t-statistics for differences in means across these samples.

Table 3 indicates significant differences between the treatment and unmatched control groups. The mean values of the current account deficit and government spending are lower, and trade openness is larger, for the treatment group than in the unmatched sample, implying economic fundamentals are better on average in countries with liberalized capital accounts. The U.S. interest rate is lower for the treatment group, suggesting that these countries benefited from the lesser attractiveness of investment opportunities in industrial economies. Governments change more often in the treatment group. These differences in means are significantly different at $5 \%$ or more for government spending, trade openness, and government changes, and at almost $10 \%$ for the current account/GDP ratio.

Comparing the treatment group with our matching control groups, however, substantially reduces the mean difference of the characteristic variables and improves the balance across the samples. None of the mean differences are significant, with the exception of openness, where openness of the control groups is much lower than that for the treatment group. Further inspection indicates this difference is attributable to Singapore, which had a liberalized capital account as well as an extremely high level of trade openness for most of the sample period. Omitting Singapore from the sample leads to an insignificant difference in means. Thus matching works well in achieving a balance of characteristics between the treated and matched observations, i.e., observations with the same propensity score have the same distribution of observable characteristics independently of their treatment status.

Table 3 also reports that there is almost a 10 percentage point difference between the predicted likelihood (i.e., mean propensity) of the treatment group having liberalized capital accounts and that of the unmatched control group ( 0.27 versus 0.17$)$. This is not surprising since 
by construction all observations in the treatment group have liberalized their capital accounts, while none of the observations in the control group have done so. Compared to the unmatched control group, the predicted likelihood of liberalized capital accounts is slightly higher for the two matched control groups -- 0.20 for the nearest neighbor procedure and 0.18 for the radius procedure, but still below the mean of the treatment group (0.27).

Some examples of country/time observations with similar propensity scores, but different treatments and outcomes, may be informative in pointing out the strengths and weaknesses of the matching methodology. Examples of "matches" using the nearest neighbor approach include: (i) Venezuela had no capital controls in 1997 and an estimated propensity score of capital account liberalization of .383. Venezuela did not experience a crisis in that year. Malta had a similar propensity score (.385) while having capital controls in place in 1992, but did experience a currency crisis. (ii) Bolivia had a liberalized capital account in 1991 and a propensity score of .303, but experienced a currency crisis. Korea in 1991 had capital controls and an identical propensity score, but did not experience a currency crisis at that time. (iii) Malaysia had no capital controls in 1991 and is matched with Swaziland which had controls in 1992. While the two countries had the same propensity score (.389), neither had a currency crisis.

These examples illustrate the fact that country experiences vary greatly across time, and the matching (nearest neighbor) procedure will pick out the observations with the closest likelihood of a liberalized capital account. As we have shown, the model has good explanatory power and predictive characteristics. Nonetheless, at each point in time the conditions associated with (or without) a currency crisis in a particular country may differ greatly. Moreover, there are many examples of matched observations of countries with and without capital controls associated with "low" as well as "high" propensity scores. For example, Panama had a liberalized capital account in 1981 but a relatively low propensity score (.119); Paraguay had capital controls in 1984 and a near identical propensity score (.120). But Panama avoided a currency crisis, while Paraguay did not.

\section{Impact of Capital Account Liberalization on Currency Crises}

\section{5a. Benchmark Matching Results}

We first estimate propensity scores from the benchmark selection equation and then employ nearest neighbor, radius, and strata matching methods to evaluate the impact of capital 
account liberalization on the frequency of currency crises. Table 4 shows that the frequency of currency crises is significantly lower in countries with liberalized capital accounts than in the matched samples with capital controls; this result is invariant to the matching method employed. Specifically, the frequency of currency crises in countries with liberalized capital accounts, compared to those with capital controls, ranges from 4.82 percentage points lower with the strata method to 5.24 percent lower with the radius measure to 7.02 percentage points lower with the nearest neighbor method. These results are economically and statistically significant (at the 5 percent level for the strata and nearest neighbor methods, at 1 percent for the radius measure).

Table 5 undertakes a robustness check. The results from the analysis reported in Table 4 do not impose any restrictions that preclude matches between different year observations for the same country. In Table 5 we consider the possibility of correlation among observations from the same country-a potential source of estimation bias-- and impose the restriction that the match(es) for each observation in the treatment group are always drawn from a different country in the control group. We report the results of matching with this restriction for both the nearest neighbor and radius measures. ${ }^{22}$ For the nearest neighbor approach the results are identical to those in Table 4, since it turns out there are no within-country observations to drop. For the radius approach, the result with only across-country observations is in fact marginally stronger, with the frequency of currency crises 5.51 percentage points lower (compared to 5.24 points in Table 4) for countries without capital controls; this result is significant at better than 1 percent.

Overall, the negative treatment effects of liberalized capital accounts reported in Tables 4 and 5 suggest that countries with liberalized capital accounts are less likely to experience a currency crisis by a magnitude of 5 to 7 percentage points. This impact is both statistically significant and economically meaningful for all matching methods. The unconditional likelihood of a currency crisis is 11.7 percent for developing countries for our sample period of 1975-97. Reducing the likelihood of a currency crisis by 5 to 7 percentage points when capital accounts are liberalized implies much less vulnerability to currency instability.

These results support previous work finding a negative (positive) link between capital account liberalization (control) and the onset of currency crises. In particular, using probit model

\footnotetext{
${ }^{22}$ With the strata measure, the treatment observations are matched with the average of observations for a control group of observations within the same stratum based on propensity scores. Hence we cannot exclude from the control group observations that match observations in the treatment group from the same country because they could also be matches for the treatment observations of another country.
} 
estimates of the likelihood of a currency crisis, Glick and Hutchison (2005) find that the marginal probability effect of contemporaneous capital controls is 11 percent in a simple bivariate equation and 8 percent when other explanatory variables are included. Their estimates fall to 9 percent and 5 percent, respectively, when capital controls are entered as lagged explanatory variables in the probit regression. Thus our matching methodology gives results of the same order of magnitude.

\section{5b. Robustness to Alternative Propensity Score Equations}

Table 6 presents robustness tests using alternative propensity scores derived from our augmented probit model of capital account liberalization that include financial development variables (col. 3 and 4 of Appendix A) as well as our institutional quality variable (col. 4 of Appendix A). Note that the inclusion of these additional variables reduces the sample size considerably; there are only 736 observations in the specification reported in column 4, compared with 1219 in the benchmark model in column 1.

The mean differences between the treatment and control groups from these augmented selection models are very similar to the benchmark results, with one exception. The benchmark results, presented in Tables 4 and 5, showed that the frequency of crises for countries with liberalized capital accounts (the treatment group) ranged from 4.82 to 7.01 percentage points lower than for the control groups. The augmented model results, reported in Table 6, show very similar effects overall, with differences ranging from 6.31 to 7.71 percentage points lower; for the radius measure the results remain significant at better than 1 percent. The exception is the mean difference associated with nearest neighbor matching that includes the institutional quality as well as financial development variables (based on the selection equation in col. 4 of Appendix A); here the difference is only 0.92 percentage points. It is noteworthy as well that neither of the nearest-neighbor matching results are statistically significant at conventional levels.

In sum, the augmented results with the radius approach are consistent with those from our benchmark specification for the selection equation. For the nearest neighbor matching, however, the results are weaker than the benchmark results in terms of significance and, for the selection

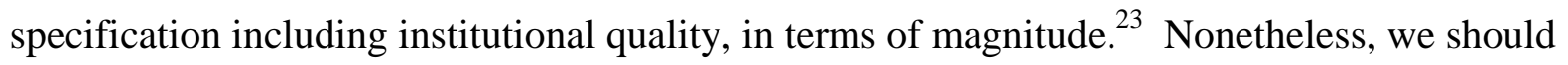

\footnotetext{
${ }^{23}$ It should be noted that the augmented propensity score models with financial development and institutional quality variables display less balance in the similarity of characteristics between the treatment and control samples
} 
emphasize that we can certainly still reject the null hypothesis that countries with liberalized capital accounts are more vulnerable to currency crises.

\section{5c. Robustness to Including Industrial Countries}

As another robustness check, we expanded the sample to include industrial as well as developing economies. ${ }^{24}$ The results for the marginal propensity score selection equations with our baseline and extended variable specifications are presented in Appendix B. ${ }^{25}$ The corresponding matching results using the nearest neighbor and radius methods are reported in Table 7.

The matching results presented in Table 7 are roughly similar to those reported when the sample was restricted to developing economies (in Tables 3 and 6), though they are not as strongly significant. For the baseline specification, the frequency of currency crises ranges from 4 to 6 percentage points lower for countries without capital controls; this difference is significant at 10 percent for the nearest neighbor method (with a t-statistic of 1.76) and at 1 percent for the radius method (with a t-statistic of 4.48) . For the augmented specification, the difference of 6 percentage points for the radius method is significant at 10 percent. Again, only for the nearest neighbor method is the effect of liberalization small and insignificant.

\section{5d. Robustness of Currency Crisis Probit Predictions to Matching}

As another robustness check, we use propensity score matching to create a matched comparison group, and then use further regression adjustment on the resulting samples to control for these additional variables in the currency crisis outcome equation. ${ }^{26}$

We implement this approach as follows. First, we construct a sample of treatment and control observations using propensity score matching based on a specification of our probit

\footnotetext{
than does the benchmark model. On the other hand, explanatory power in predicting capital account liberalization is improved in the augmented models.

24 The crisis dates and liberalization episodes for the industrial countries are available upon request.

${ }^{25}$ Comparison of augmented selection equations with the developing country sample (cf. col. 2 of Appendix B with col. 4 of Appendix A) indicates that the current account/GDP, government spending, financial repression, and institutional quality variables all have the same signs and are significant. However, with industrial countries included the government change variable is negative (and significant at 1\%), suggesting that more frequent changes in government indicate less political stability that lessens the likelihood of capital account liberalization. In addition, the real interest rate has a negative (and significant at 1\%) effect, implying capital account liberalization is more likely to occur when interest rates are low. The openness and credit/GDP variables are no longer significant.

${ }^{26}$ We thank a referee for suggesting this approach.
} 
selection equation. ${ }^{27}$ Using this sample, we then estimate a probit model of currency crises, where the occurrence of a currency crisis is the dependent variable and the righthand side variables include the state of capital account liberalization as well as a set of explanatory variables used to predict currency crises. This specification of the crisis prediction equation is intended to control for factors other than capital account liberalization that may affect the likelihood of currency crises. The coefficient on the capital liberalization variable in this equation corresponds to the difference of means for our matching procedures.

To implement this procedure, we follow Glick and Hutchison (2005) in identifying the variables for inclusion in the currency crisis equation. Their basic model includes five macroeconomic control variables (all are lagged to limit simultaneity problems). These variables are the log ratio of broad money to foreign reserves, domestic credit growth, the current account to GDP ratio, real GDP growth, and real exchange rate overvaluation ${ }^{28}$.

Table 8 reports the results for our matched samples from propensity scoring equations using our baseline and two augmented specifications of our selection equation. Since the variables and corresponding data availability varies across these specifications, the sample size varies as well, with 285, 176, and 170 available observations, respectively. For each sample, we estimate probit equations indicating the likelihood of currency crises. As expected, the M2/foreign reserves ratio and domestic credit growth are positively associated with currency crises. Current account surpluses, real overvaluation, and strong real GDP growth are associated with a lower frequency of currency crises. The explanatory variables all have the expected signs. $^{29}$

\footnotetext{
${ }^{27}$ The matches are based on the nearest neighbor approach.

${ }^{28}$ The data are drawn from the IMF IFS CD-ROM: log ratio of broad money to foreign reserves (lines 34 plus 35 divided by 1ld times ae), domestic credit growth (line 32), the current account to GDP ratio (line 78ald times xrrf divided by 99b) real GDP growth (line 99b.r or 99b.p), and real exchange rate overvaluation. The latter variable is constructed as the degree of real exchange rate overvaluation from deviations from a fitted trend in the real tradeweighted exchange rate index, where the exchange rate index we fit is the annual average of the monthly series used in constructing the exchange rate component of our currency pressure index.

${ }^{29}$ As an additional robustness check, we included all of the currency crisis equation explanatory variables (e.g. overvaluation, M2/reserves, etc.) in the propensity score selection equation together with the benchmark determinants of capital account liberalization. The difference in means in currency crisis outcomes for the matched samples based on this equation gave results (not reported in the paper) that were very similar though less significant than the other matching results. In particular, the differences in means between the treatment and control groups were -5.15 with nearest neighbor matching and -4.21 with radius matching. We interpret this result as supporting our exclusion restriction of not including the crisis equation explanatory variables in the propensity score equations in Appendix A.
} 
The point estimate on the capital account coefficient in the probit equations explaining currency crises (ranging from -4.22 to -6.71 ) is very similar to the difference in means of the treatment and control samples based on the matching methodology. The results in Table 8 confirm the implications from our other matching methods: countries with less restrictive capital controls tend to be less vulnerable to speculative attacks. Thus conditioning the probit estimates of the likelihood of currency crises on the determinants of capital account liberalization indicates that capital account liberalization still reduces the likelihood of currency crises.

\section{Explanations and Concluding Remarks}

Whether countries that allow international capital to flow more freely subject themselves to greater risk of currency and balance of payments turmoil is an important empirical question. We argue that in order to analyze empirically the association of currency crises with the extent of capital account liberalization attention should be given to the environment in which countries liberalize their capital accounts — freedom of international capital movements may be associated with less vulnerability to currency crises in large part due to the special characteristics and "self selection" of countries that choose to liberalize.

In particular, countries with relatively balanced macroeconomic policies, strong financial sectors, political stability, and/or institutional stability may choose to liberalize their capital accounts because they want to take advantage of long-run efficiency gains in the allocation of capital and are not overly concerned with external crises. By contrast, countries with capital controls may hope to avoid difficult economic reforms or to avoid capital outflows that may trigger a crisis. This implies that countries with sound macroeconomic and political environments and more robust financial systems and institutions may not only be less likely to experience crises, but also less likely to enact capital controls and forego the benefits of free capital flows. Consequently, countries with closed capital accounts may be more prone to financial crises, both domestic and international in origin. Although capital account liberalization may increase country vulnerability to crises in some cases, capital controls can still be associated with a greater overall likelihood of financial crises.

We address this issue by employing the matching and propensity score methodology that was developed precisely for this type of sample selection bias. Methods of matching were developed to help account for the estimation bias arising from the "selection on observables" 
problem. We use “nearest neighbor”, "radius,” and "stratification” matching methods that are designed to account for selection on observables bias.

All of our results suggest that, even after controlling for sample selection bias, capital restrictions are associated with a greater likelihood of currency crises. That is, when two countries have the same likelihood of maintaining a liberalized capital account (based on historical evidence and a very similar set of identical economic and political characteristics at a point in time)—and one country imposes controls and the other does not-- the country without controls has a lower likelihood of experiencing a currency crisis. These results are robust to changes in the type of methodology and in the equations that predict the likelihood of capital account liberalization. The point estimates suggest that countries without capital controls are less likely to experience a currency crisis in any given year. Even in cases where the point estimates are weaker (i.e., with the inclusion of institutional quality in the selection equation and the use of nearest neighbor matching), we can certainly still reject the null hypothesis that countries with liberalized capital accounts are more vulnerable to currency crises.

We conclude by discussing possible explanations for our result. Arguments in favor of capital controls are well known (see Dooley, 1996). They include second-best arguments suggesting the desirability of controls as a means of offsetting some existing distortion in an economy's financial or fiscal structure, such as a weak tax base or the mispricing of risk by domestic financial institutions engaged in international borrowing or lending. They also include support for controls as a first-best response to the possibility of multiple equilibria, with speculative currency attacks generated by self-fulfilling changes in private expectations not necessarily related to economic fundamentals.

But the actual effectiveness of capital controls is another matter. A number of empirical studies suggest that capital controls have not been particularly effective in preventing currency crises. For example, capital controls are unlikely to be effective in preventing currency crises associated with policy inconsistencies between inappropriate exchange rate pegs and macroeconomic policy stances. In addition, as Edwards (1999) argues, legal capital restrictions frequently prove ineffective, and are easily sidestepped by domestic and foreign residents and firms, more so over time. In fact, a number of empirical studies have found little effect of capital controls in averting currency crises, at least not without other supporting economic policies. For example, using various econometric tests and a detailed case study of Chilean controls imposed 
in the 1980s, Edwards (1999) finds that “...the relative absence of contagion effect on Chile [during the currency crises of the 1990s] is due to its sturdy banking regulation and not to its capital controls policy” (p. 22). Edison and Reinhart (2001a) focus on the recent experiences of several emerging markets and conclude that they "did not deliver much of what was intended.”30 Kaminsky and Schmukler (2001), find little evidence in a six-country study that controls effectively segment domestic markets from foreign markets. These findings are supported by Edwards' (1989) analysis of the role of capital controls in thirty-nine devaluation episodes for twenty-four developing countries over the period 1961-82. He finds that countries typically intensified their control programs in the year before devaluation, and concludes that "[a]t most one can argue that these heightened impediments to trade managed to slow down the unavoidable balance of payments crisis” (pp. 189-90). Our results for a larger sample of developing countries are consistent with this literature and the finding that capital account liberalization does not raise a country’s vulnerability to currency instability.

But how do we explain our finding that capital account liberalization may reduce a country’s vulnerability to currency instability, or conversely why capital controls raise a country's exposure? There are several possible explanations related to the role of limited information or to the existence of multiple equilibria. ${ }^{31}$

Dooley and Isard (1980) point out that controls preventing investors from withdrawing capital from a country act like a form of investment irreversibility: by making it more difficult to get capital out in the future, controls may make investors less willing to invest in a country. Following this reasoning, Bartolini and Drazen (1997a, b) show that imposing capital controls can send a signal of inconsistent and poorly designed future government policies. ${ }^{32}$ Thus, the controls intended to curtail outflows may, in fact, provoke more outflows because they reduce investors' confidence. Conversely, adoption of a regime of capital account openness can provide a signal that future policies are likely to be more favorable to investment. It may also enhance the

\footnotetext{
${ }^{30}$ Malaysia in 1998 is an exception to this conclusion. This is consistent with the results and interpretation of Kaplan and Rodrik (2001). That China and India, both countries with capital controls, successfully avoided the Asian crisis of 1997-98, is often cited as evidence of the effectiveness of controls. Our results do not suggest that capital controls are never effective, but refer to average effects over a large number of episodes.

31 Similar arguments are presented by Cavallo and Frankel (2004) to explain why less protectionism and greater trade openness reduces a country's vulnerability to "sudden stop" crises. They find that trade protectionism does not "shield" countries from the volatility of world markets; to the contrary, less trade openness leads to greater vulnerability to sudden stops.

${ }^{32}$ In the Bartolini and Drazen (1997) model the signaling role of capital controls policy arises because investors have imperfect information about government intentions.
} 
credibility of a broader reform program. Hence, the removal of controls on capital outflows may generate capital inflows, thereby lessening pressure for currency depreciation.

Another possible explanation hinges on the possibility of currency crises associated with multiple equilibria, with speculative currency attacks generated by self-fulfilling changes in private expectations. Dellas and Stockman (1993) and Dooley (1996), for example, point out that the existence of multiple equilibria cuts both ways, and does not necessarily warrant the use of capital controls, since they may actually destabilize expectations. For example, changing beliefs about the imposition of controls may lead the market to reassess the equilibrium of the currency and hence challenge it. Moreover, foreign investors would be less likely to pull out of a country with an open capital market if they know the country is less likely to reimpose controls or default.

These are several possible channels through which capital account liberalization may lead to greater currency stability. We conclude with a caveat. Our results, based on the historical record, indicate that capital account liberalization is on balance associated with greater currency stability even after controlling for self-selection into regimes with freer movement of international capital. However, the results do not indicate that all liberalized regimes are associated with greater currency stability, nor that all regimes with capital controls are necessarily associated with more currency instability. Our results are based on average effects calculated over many countries and episodes. Exceptions to the average effect are clearly evident and closer examination of these cases, based on more detailed information on the nature of capital controls, is on our agenda for future research. 


\section{$\underline{\text { References }}$}

Alesina, Alberto, Vittorio Grilli, and G.-M. Milesi-Ferretti, 1994. "The Political Economy of Capital Controls,” In Leonardo Leiderman and Assaf Razin, eds., Capital Mobility: The Impact on Consumption, Investment and Growth. Cambridge, UK: Cambridge University Press, pp. 289321.

Bartolini, Leonardo and Allan Drazen, 1997a. “Capital Account Liberalization as a Signal,” American Economic Review 87: 138-54.

Bartolini, Leonardo and Allan Drazen, 1997b. "When Liberal Policies Reflect External Shocks, What Do We Learn?” Journal of International Economics 42: 249-73.

Dehejia, R. H., and S. Wahba, 2002. "Propensity Score Matching Methods for Non-experimental Causal Studies.” Review of Economics and Statistics 84(1): 151-161.

Demirguc-Kunt, Asli and Ross Levine 2001. "Bank-based and Market-based Financial Systems: Cross-Country Comparisons,” In Asli Demirguc-Kunt and Ross Levine (eds.) Financial Structure and Economic Growth, A Cross-Country Comparison of Banks, Markets, and Development, Cambridge, MA: MIT Press.

Dooley, Michael, 1996. “A Survey of the Literature on Controls over International Capital Transactions,” IMF Staff Papers 43 (4): 639-687. and Peter Isard, 1980. "Capital Controls, Political Risk, and Deviations from

Interest Rate Parity. Journal of Political Economy 88(2): 370-84.

Easterly, William and Ross Levine, 1997. “Africa’s Growth Tragedy: Policies and Ethnic Divisions,” Quarterly Journal of Economics 112 (November): 1203-50. , 2003. "Tropics, Germs, and Crops: How Endowments Influence Economic Development,” Journal of Monetary Economics 50 (January): 3-39.

Edison, H.J., M. Klein, L. Ricci, L., and T. Slok, 2002. “Capital Account Liberalization and Economic Performance: Survey and Synthesis.” NBER Working Paper no. 9100. Cambridge, MA.

Edison, H.J., and C.M. Reinhart, 2001a. "Capital Controls during Financial Crises: the Cases of Malaysia and Thailand,” In: Glick, R., Moreno, R., Spiegel, M.M., (Eds.), Financial Crises in Emerging Markets, Cambridge University Press, Cambridge, UK, Chapter 12. Also issued as International Finance Discussion Paper no. 662 (March). Board of Governors of the Federal Reserve System. Washington, DC.

Edison, H.J., and C.M. Reinhart, 2001b. “Stopping Hot Money," Journal of Development Economics 66(2): 533-553.

Edwards, S., 1999. “On Crisis Prevention: Lessons from Mexico and East Asia.” NBER Working Paper no. 7233. Cambridge, MA. 
Frankel, Jeffrey A., and Eduardo Cavallo. 2004. "Does Openness to Trade Make Countries More Vulnerable to Sudden Stops, or Less? Using Gravity to Establish Causality." Kennedy School of Government Working Paper Series RWP04-038, August.

Frankel, J., and A. Rose, 1996. "Currency Crashes in Emerging Markets: An Empirical Treatment,” Journal of International Economics 41 (3/4): 351-366.

Glick, Reuven and Michael Hutchison, 2005. "Capital Controls and Exchange Rate Instability in Developing Economies,” Journal of International Money and Finance, April.

Gourinchas, Pierre-Olivier and Olivier Jeanne 2003. “The Elusive Gains from International Financial Integration.” NBER Working Paper no. 9684. Cambridge, MA.

Gregorio, J., S. Edwards, and R. Valdes, 2000. “Controls on Capital Inflows: Do They Work?” NBER Working Paper no. 7645. Cambridge, MA.

Grilli, Vittorio and G.-M. Milesi-Ferretti 1995. "Economic Effects and Structural Determinants of Capital Controls,” IMF Staff Papers 42 (3): 517-51.

Harris, Dellas and Alan Stockman. 1993. "Self-Fulfilling Expectations, Speculative Attack, and Capital Controls." Journal of Money, Credit, and Banking 25: 721-730.

Heckman, James and Salvador Navarro-Lozano, 2004. "Matching, Instrumental Variables and Control Functions,” Review of Economics and Statistics 86(1): 30-57

Heckman, James J., Hidehiko Ichimura, and Petra E. Todd, 1998. "Matching as an Econometric Evaluation Estimator,” Review of Economic Studies 65 (2): 261-294.

Hutchison, Michael M., 2004. "Selection Bias and the Output Cost of IMF Programs," University of California, Santa Cruz, Discussion Paper.

International Monetary Fund (various issues). Annual Report on Exchange Arrangements and Exchange Restrictions. Washington, DC.

International Monetary Fund, 2003. World Economic Outlook, April 2003, Chapter 3.

Washington, DC.

Kaminsky, Graciela and Sergio Schmukler , 2001. "Short- and Long-Run Integration: Do Capital Controls Matter?” World Bank Working Paper no. 2660

Kaminsky, Graciela, Saul Lizondo, and Carmen Reinhart, 1998. "Leading Indicators of Currency Crises,” IMF Staff Papers 45 (March): 1-48.

Kaminsky, Graciela and Carmen Reinhart, 1999. "The Twin Crises: The Causes of Banking and Balance-of-Payments Problems,” American Economic Review 89 (June): 473-500.

Kaplan, Ethan and Dani Rodrik, 2001. “Did the Malaysian Capital Controls Work?” National Bureau for Economic Research no. 8142. 
Kaufmann, Daniel, Aart Kraay, and Pablo Zoido-Lobatón, 1999a. “Aggregating Governance Indicators,” World Bank Policy Research Working Paper no. 2195. Washington, DC .

—_, 1999b. “Governance Matters,” World Bank Policy Research Working Paper no. 2196, Washington, DC.

Knack, Stephen and Philip Keefer, 1995. "Institutions and Economic Performance: CrossCountry Tests Using Alternative Institutional Measures,” Economics and Politics 7: S. 207-227

Mauro, P., 1995. ”Corruption and Growth,” Quarterly Journal of Economics 110: 681-712.

Persson, T., 2001. “Currency Unions and Trade: How Large is the Treatment Effect?” Economic Policy (October): 435-448.

Rosenbaum, Paul R. and Donald B. Rubin, 1983, "The Central Role of the Propensity Score in Observational Studies for Causal Effects,” Biometrika, 70(1): 41-55.

Rosenbaum, Paul R. and Donald B. Rubin, 1985. "Constructing a Control Group Using Multivariate Matched Sampling Methods that Incorporate the Propensity Score," American Statistician 39(1): 33-38.

Roubini, Nouriel and Xavier Sala-i-Martin, 1992. "Financial Repression and Economic Growth,” Journal of Development Economics 39: 5-30.

Rubin, D. B., and N. Thomas, 1992. "Characterizing the Effect of Matching Using Linear Propensity Score Methods with Normal Distributions,” Biometrika 79(4): 797-809. 
Table 1. Currency Crises and Capital Account Liberalization, Unconditional Frequency (in percent)

\begin{tabular}{|l|c|c|c|c|c|c|}
\hline & $\begin{array}{r}\mathbf{1 9 7 5 -} \\
\mathbf{1 9 9 7}\end{array}$ & $\begin{array}{r}\mathbf{1 9 7 5 -} \\
\mathbf{1 9 7 9}\end{array}$ & $\begin{array}{r}\mathbf{1 9 8 0 -} \\
\mathbf{1 9 8 4}\end{array}$ & $\begin{array}{r}\mathbf{1 9 8 5 -} \\
\mathbf{1 9 8 9}\end{array}$ & $\begin{array}{r}\mathbf{1 9 9 0 -} \\
\mathbf{1 9 9 4}\end{array}$ & $\begin{array}{r}\mathbf{1 9 9 5 -} \\
\mathbf{1 9 9 7}\end{array}$ \\
\hline Currency crises $^{\mathrm{a}}$ & 11.7 & 9.9 & 12 & 14.3 & 11.8 & 9.7 \\
\hline (Number of crises) $^{(160)}$ & $\mathbf{( 2 6 )}$ & $\mathbf{( 3 4 )}$ & $\mathbf{( 4 3 )}$ & $\mathbf{( 3 8 )}$ & $(19)$ \\
\hline Liberalization $^{\mathrm{b}}$ & 16.2 & 20.6 & 15.8 & 11.0 & 13.4 & 23.8 \\
\hline
\end{tabular}

a Number of crises divided by total country-years with available data. Number of crises is in parentheses.

b Number of country-years with capital account liberalization divided by total country-years with available data.

Table 2. Currency Crises, Frequency Conditional on Capital Account Liberalization (in percent)

\begin{tabular}{|l|c|c|c|}
\hline & Yes $^{\mathbf{a}}$ & $\mathbf{N o}^{\mathbf{b}}$ & $\chi^{\mathbf{2 c}}$ \\
\hline $\begin{array}{l}\text { Liberalization in place during } \\
\text { current year? }\end{array}$ & 6.8 & 12.7 & $6.11^{* *}$ \\
\hline $\begin{array}{l}\text { Liberalization in place during } \\
\text { previous year? }\end{array}$ & 8.0 & 12.5 & $3.50^{*}$ \\
\hline
\end{tabular}

${ }^{a}$ Number of currency crises for which capital account liberalization in place at end of current or previous year, divided by total number of country-years with liberalization in place.

${ }^{b}$ Number of currency crises for which capital account liberalization in place at end of current or previous year, divided by total number of country-years with liberalization in place.

${ }^{\mathrm{c}}$ Null hypothesis of independence between frequency of currency crises and capital account liberalization is distributed as $\chi^{2}(1)$. Note: ** and * indicate rejection of null at 5 and 10 percent significance levels, respectively. 
Table 3. Sample Characteristics of Treatment and Control Groups

\begin{tabular}{|c|c|c|c|c|c|c|c|}
\hline Variable & $\begin{array}{c}\begin{array}{c}\text { Treatment } \\
\text { Group }\end{array} \\
\mu_{T}\end{array}$ & $\begin{array}{c}\text { Unmatched } \\
\text { Control } \\
\text { Group } \\
\mu_{C}\end{array}$ & $\begin{array}{l}\text { t-statistic } \\
H_{0}: \mu_{T}=\mu_{C}\end{array}$ & $\begin{array}{c}\text { Matched } \\
\text { Control } \\
\text { Group } \\
\text { (Nearest } \\
\text { Neighbor) } \\
\mu_{C N} \\
\end{array}$ & $\begin{array}{l}\text { t-statistic } \\
H_{0}: \mu_{T}=\mu_{C N}\end{array}$ & $\begin{array}{c}\text { Matched } \\
\text { Control } \\
\text { Group } \\
\text { (radius } \\
<\mathbf{0 . 0 0 5} \text { ) } \\
\mu_{C R} \\
\end{array}$ & $\begin{array}{l}\text { t-statistic } \\
H_{0}: \mu_{T}=\mu_{C R}\end{array}$ \\
\hline $\begin{array}{l}\text { Current } \\
\text { account/GDP }\end{array}$ & $\begin{array}{l}-3.01 \\
(7.07)\end{array}$ & $\begin{array}{l}-4.00 \\
(7.29)\end{array}$ & -1.62 & $\begin{array}{l}-2.49 \\
(5.44)\end{array}$ & 0.71 & $\begin{array}{l}-3.67 \\
(5.58)\end{array}$ & -1.14 \\
\hline $\begin{array}{l}\text { Govt. } \\
\text { spending/GDP }\end{array}$ & $\begin{array}{l}12.49 \\
(3.88)\end{array}$ & $\begin{array}{l}13.93 \\
(5.69)\end{array}$ & $4.03 * * *$ & $\begin{array}{l}12.28 \\
(5.36)\end{array}$ & -0.37 & $\begin{array}{l}12.90 \\
(4.98)\end{array}$ & 1.16 \\
\hline Trade openness & $\begin{array}{c}79.11 \\
(85.52)\end{array}$ & $\begin{array}{c}51.60 \\
(33.56)\end{array}$ & $-4.14 * * *$ & $\begin{array}{c}52.75 \\
(38.61)\end{array}$ & $-3.56 * * *$ & $\begin{array}{c}51.03 \\
(32.73)\end{array}$ & $-4.22 * * *$ \\
\hline $\begin{array}{l}\text { U.S. real } \\
\text { interest rate }\end{array}$ & $\begin{array}{c}2.83 \\
(2.25)\end{array}$ & $\begin{array}{c}3.03 \\
(2.21)\end{array}$ & 1.07 & $\begin{array}{c}2.91 \\
(2.06)\end{array}$ & 0.33 & $\begin{array}{c}3.06 \\
(2.15)\end{array}$ & 1.25 \\
\hline $\begin{array}{l}\text { Change of } \\
\text { govt. }\end{array}$ & $\begin{array}{c}4.34 \\
(3.11)\end{array}$ & $\begin{array}{c}3.79 \\
(2.56)\end{array}$ & $-2.15^{* *}$ & $\begin{array}{c}4.31 \\
(2.75)\end{array}$ & -0.09 & $\begin{array}{c}4.13 \\
(2.31)\end{array}$ & -0.81 \\
\hline $\begin{array}{l}\text { Mean } \\
\text { propensity } \\
\text { scores }\end{array}$ & $\begin{array}{c}0.27 \\
(0.22)\end{array}$ & $\begin{array}{c}0.17 \\
(0.10)\end{array}$ & & $\begin{array}{c}0.20 \\
(0.10)\end{array}$ & & $\begin{array}{c}0.18 \\
(0.08)\end{array}$ & \\
\hline $\begin{array}{l}\text { No. of } \\
\text { observations }\end{array}$ & 171 & 831 & & 124 & & 680 & \\
\hline
\end{tabular}

Note: Table reports the sample mean of variables for the treatment group $\mu_{T}$ (i.e. country-years with liberalized capital accounts), for the unmatched control group $\mu_{C}$ (i.e. country-years with capital controls), and for matched control groups based on propensity scores estimated by the benchmark selection specification reported in column (1) of Appendix A, using the nearest neighbor method $\left(\mu_{C N}\right)$ or radius method $\left(\mu_{C R}\right)$; associated standard errors are in parenthesis. t-statistics for difference of means between the treatment group and control groups are reported in adjacent column. Results significant at 1, 5, and 10 percent levels are indicated by ***,**, and *, respectively. 
Table 4. Benchmark Matching Results: Including Within-Country Observations

\begin{tabular}{|l|c|c|c|}
\hline & Nearest-Neighbor & Radius (<0.005) & Strata \\
\hline $\begin{array}{l}\text { Estimated effect of } \\
\text { liberalization (percent) }\end{array}$ & -7.02 & -5.24 & -4.82 \\
\hline t-statistic & $-2.07^{* *}$ & $-3.49 * * *$ & $-2.01^{* *}$ \\
\hline $\begin{array}{l}\text { No. of observations in the } \\
\text { treatment group } \\
\text { (No. of observations in the } \\
\text { control group) }\end{array}$ & 171 & 171 & 171 \\
\hline
\end{tabular}

Note: Table reports difference in frequency of currency crises for matched observations with and without liberalized current accounts. Matching is based on the propensity scores estimated by benchmark selection specification reported in column (1) in Appendix A. Results significant at 1, 5, and 10 percent levels are indicated by ***,**, and *, respectively.

Table 5. Benchmark Matching Results: Only Across-Country Observations

\begin{tabular}{|l|c|c|}
\hline & Nearest-Neighbor & Radius (<0.005) \\
\hline $\begin{array}{l}\text { Estimated effect of } \\
\text { liberalization (percent) }\end{array}$ & -7.02 & -5.51 \\
\hline t-statistic & $-2.07^{* *}$ & $-3.69^{* * *}$ \\
\hline $\begin{array}{l}\text { No. of observations in the } \\
\text { treatment group } \\
\text { (No. of observations in the } \\
\text { control group) }\end{array}$ & 171 & 171 \\
\hline
\end{tabular}

Note: See Table 4. 
Table 6. Robustness: Matching Results with Augmented Selection Equation

\begin{tabular}{|l|c|c|c|c|}
\hline & \multicolumn{2}{|c|}{$\begin{array}{c}\text { With Financial Development } \\
\text { Variables }\end{array}$} & \multicolumn{2}{c|}{$\begin{array}{c}\text { With Financial Development } \\
\text { and Institutional Quality } \\
\text { Variables }\end{array}$} \\
\hline & $\begin{array}{c}\text { Nearest- } \\
\text { Neighbor }\end{array}$ & $\begin{array}{c}\text { Radius } \\
(<\mathbf{0 . 0 0 5})\end{array}$ & $\begin{array}{c}\text { Nearest- } \\
\text { Neighbor }\end{array}$ & $\begin{array}{c}\text { Radius } \\
(<\mathbf{0 . 0 0 5})\end{array}$ \\
\hline $\begin{array}{l}\text { Estimated effect of } \\
\text { liberalization (percent) }\end{array}$ & -6.31 & -7.71 & -0.92 & -7.61 \\
\hline t-statistic & -1.54 & $-4.32^{* * *}$ & -0.25 & $-3.95^{* * *}$ \\
\hline $\begin{array}{l}\text { No. of observations in } \\
\text { the treatment group } \\
\text { (No. of observations in } \\
\text { the control group) }\end{array}$ & 111 & 111 & 109 & 109 \\
\hline
\end{tabular}

Note: Table reports difference in frequency of currency crises for matched observations with and without liberalized current accounts. Matching is based on the propensity scores estimated by augmented selection specifications (including financial development and institutional quality) reported in columns (3) and (4) of Appendix A, respectively. Results significant at 1, 5, and 10 percent levels are indicated by $* * *, * *$, and $*$, respectively.

Table 7. Robustness: Matching Results with Industrial Countries Included

\begin{tabular}{|l|c|c|c|c|}
\hline & \multicolumn{2}{|c|}{ Benchmark Selection } & \multicolumn{2}{c|}{ Augmented Selection } \\
\hline & $\begin{array}{c}\text { Nearest- } \\
\text { Neighbor }\end{array}$ & $\begin{array}{c}\text { Radius } \\
(<\mathbf{0 . 0 0 5})\end{array}$ & $\begin{array}{c}\text { Nearest- } \\
\text { Neighbor }\end{array}$ & $\begin{array}{c}\text { Radius } \\
(<\mathbf{0 . 0 0 5})\end{array}$ \\
\hline $\begin{array}{l}\text { Estimated effect of } \\
\text { liberalization (percent) }\end{array}$ & -3.98 & -6.33 & -0.69 & -4.75 \\
\hline t-statistic & $-1.76^{*}$ & $-4.48^{* * *}$ & -0.30 & $-1.86^{*}$ \\
\hline $\begin{array}{l}\text { No. of observations in } \\
\text { the treatment group } \\
\text { (No. of observations in } \\
\text { the control group) }\end{array}$ & 352 & 352 & 290 & 290 \\
\hline
\end{tabular}

Note: Table reports difference in frequency of currency crises for matched observations with and without liberalized current accounts for developing and industrial countries. Matching is based on the propensity scores estimated for benchmark and augmented selection equations reported in columns (1) and (2) of Appendix B. Results significant at 1, 5, and 10 percent levels are indicated by ***, **, and ${ }^{*}$, respectively. 
Table 8. Robustness: Currency Crisis Likelihood for Matched Samples

\begin{tabular}{|c|c|c|c|}
\hline $\begin{array}{l}\text { Explanatory } \\
\text { Variable }\end{array}$ & $\begin{array}{c}\text { Benchmark } \\
\text { Selection }\end{array}$ & $\begin{array}{c}\text { Augmented } \\
\text { Selection with } \\
\text { Financial } \\
\text { Development } \\
\text { Variables }\end{array}$ & $\begin{array}{c}\text { Augmented } \\
\text { Selection with } \\
\text { Financial } \\
\text { Development and } \\
\text { Institutional } \\
\text { Quality Variables }\end{array}$ \\
\hline $\begin{array}{l}\text { Capital Account } \\
\text { Liberalization t }\end{array}$ & $\begin{array}{l}-6.71 * * \\
(-1.98)\end{array}$ & $\begin{array}{l}-5.62 * \\
(-1.85)\end{array}$ & $\begin{array}{r}-4.22 \\
(-0.41)\end{array}$ \\
\hline Log M2/Reserve t-1 & $\begin{array}{r}1.09 \\
(1.28) \\
\end{array}$ & $\begin{array}{c}2.62 * * * \\
(3.00)\end{array}$ & $\begin{array}{r}0.59 \\
(0.32) \\
\end{array}$ \\
\hline Credit Growth t-1 & $\begin{array}{l}-0.0015 \\
(-0.05)\end{array}$ & $\begin{array}{c}-0.02 \\
(-0.86)\end{array}$ & $\begin{array}{l}-0.0043 \\
(-0.10)\end{array}$ \\
\hline Real Overvaluation t-1 & $\begin{array}{c}0.11^{*} \\
(1.88)\end{array}$ & $\begin{array}{c}0.02 \\
(0.56)\end{array}$ & $\begin{array}{r}0.06 \\
(0.78)\end{array}$ \\
\hline Real GDP Growth t-1 & $\begin{array}{l}-0.43^{* *} \\
(-2.54)\end{array}$ & $\begin{array}{r}-0.25 \\
(-1.20)\end{array}$ & $\begin{array}{c}-0.37 \\
(-1.58)\end{array}$ \\
\hline No. of observations & 285 & 176 & 170 \\
\hline $\begin{array}{l}\text { Percent of currency } \\
\text { crisis observations } \\
\text { correctly predicted }\end{array}$ & 45.2 & 57.9 & 61.5 \\
\hline $\begin{array}{l}\text { Percent of tranquil } \\
\text { observations correctly } \\
\text { predicted }\end{array}$ & 83.5 & 74.5 & 81.5 \\
\hline Log likelihood & -48.88 & -26.85 & -21.61 \\
\hline Pseudo-R2 & 0.4273 & 0.4607 & 0.3959 \\
\hline
\end{tabular}

Notes: Table reports results from probit equations for the change in the probability of a crisis in response to a 1 unit change in the variable, evaluated at the mean of all variables ( $\mathrm{x} 100$, to convert into percentages). Associated z-statistic (for hypothesis of no effect) in parentheses below are based on bootstrapped standard errors. Results significant at 1, 5, and 10 percent levels are indicated by $* * *, * *$, and $*$, respectively. Constant included, but not reported. Observations are weighted by real GDP per capita (in dollars). Columns (1), (2) and (3) correspond to selection equations reported in columns (1), (3) and (4), respectively, in Appendix A. Thresholds for correct predictions are given by the unconditional frequencies of currency crisis (i.e. the ratios of number of country-years with currency crisis to the total country-years with available data); for the three samples, these are $11.18 \%, 10.81 \%$, and $8.84 \%$, respectively. 
Appendix A.

\section{Benchmark and Augmented Probit Selection Equations for Estimating Capital Account Liberalization Propensity Scores}

\begin{tabular}{|l|c|c|c|c|}
\hline Explanatory Variable & $\mathbf{( 1 )}$ & $\mathbf{( 2 )}$ & $\mathbf{( 3 )}$ & $\mathbf{( 4 )}$ \\
\hline Current Account/GDP t-1 & $\begin{array}{c}0.59^{* *} \\
(2.36)\end{array}$ & $\begin{array}{c}0.64^{* *} \\
(2.52)\end{array}$ & $\begin{array}{c}0.50 \\
(1.30)\end{array}$ & $\begin{array}{c}0.52 \\
(1.39)\end{array}$ \\
\hline Govt. Spending/GDP t-1 & $\begin{array}{c}-1.06^{* * *} \\
(-3.50)\end{array}$ & $\begin{array}{c}-1.30^{* * *} \\
(-4.56)\end{array}$ & $\begin{array}{c}-2.03^{* * *} \\
(-4.31)\end{array}$ & $\begin{array}{c}-1.66^{* * *} \\
(-3.65)\end{array}$ \\
\hline Openness t & $\begin{array}{c}0.26^{* * *} \\
(11.31)\end{array}$ & $\begin{array}{c}0.23^{* * *} \\
(8.01)\end{array}$ & $\begin{array}{c}0.32^{* * *} \\
(4.19)\end{array}$ & $\begin{array}{c}0.27^{* * *} \\
(3.46)\end{array}$ \\
\hline U.S. Real Interest Rate t-1 & $\begin{array}{c}0.53 \\
(0.63)\end{array}$ & $\begin{array}{c}0.58 \\
(0.70)\end{array}$ & $\begin{array}{c}0.05 \\
(0.46)\end{array}$ & $\begin{array}{c}-0.01 \\
(-0.009)\end{array}$ \\
\hline Total Changes of Government t & $\begin{array}{c}2.75^{* * *} \\
(4.73)\end{array}$ & $\begin{array}{c}2.58^{* * *} \\
(4.86)\end{array}$ & $\begin{array}{c}1.22 \\
(1.56)\end{array}$ & $\begin{array}{c}1.51^{*} \\
(1.81)\end{array}$ \\
\hline Private Credit/GDP t-1 & $\begin{array}{c}-0.12 \\
(-2.63)\end{array}$ & $\begin{array}{c}-0.37^{* * *} \\
(-2.93)\end{array}$ \\
\hline Financial Repression t & & $\begin{array}{c}-5.67 * \\
(-1.78)\end{array}$ & $\begin{array}{c}-4.08 \\
(-1.32)\end{array}$ \\
\hline Institutional Quality & 1219 & 1193 & 867 & $(5.88)$ \\
\hline No. of observations & 61.6 & 63.2 & 58.0 & 736 \\
\hline $\begin{array}{l}\text { Percent of liberalization } \\
\text { observations correctly predicted }\end{array}$ & 51.7 & 52.1 & 53.2 & 67.2 \\
\hline $\begin{array}{l}\text { Percent of capital control } \\
\text { observations correctly predicted }\end{array}$ & -556.47 & -547.42 & -354.31 & -300.98 \\
\hline Log likelihood & 0.3665 & 0.3787 & 0.3855 & 0.4298 \\
\hline Pseudo-R2 & & & \\
\hline
\end{tabular}

Note: Table reports the change in the probability of capital account liberalization in response to a 1 unit change in the variable, evaluated at the mean of all variables (x 100, to convert into percentages). Associated z-statistic (for hypothesis of no effect) based on bootstrapped standard errors in parentheses below. Results significant at 1, 5, and 10 percent levels are indicated by $* * *, * *$, and *, respectively. Constant included, but not reported. Observations are weighted by real GDP per capita (in dollars). Threshold for correct predictions given by $16.2 \%$, the unconditional frequency of capital account liberalization; see Table 1. 


\section{Appendix B.}

Probit Equations for Estimating Capital Account Liberalization Propensity Scores, with Industrial and Developing Countries

\begin{tabular}{|c|c|c|}
\hline Explanatory Variable & (1) & (2) \\
\hline Current account/GDP t-1 & $\begin{array}{l}2.55^{* * *} \\
(8.91)\end{array}$ & $\begin{array}{l}1.60 * * * \\
(3.64)\end{array}$ \\
\hline Govt. spending/GDP t-1 & $\begin{array}{l}0.88^{* * *} \\
(3.55)\end{array}$ & $\begin{array}{c}-1.24 * * * \\
(3.06) \\
\end{array}$ \\
\hline Openness t & $\begin{array}{c}-0.0027 \\
(0.09) \\
\end{array}$ & $\begin{array}{l}-0.017 \\
(0.37) \\
\end{array}$ \\
\hline U.S. real interest rate $\mathrm{t}-1$ & $\begin{array}{c}0.06 \\
(0.11)\end{array}$ & $\begin{array}{c}-2.83^{* * *} \\
(3.45)\end{array}$ \\
\hline Total changes of government & $\begin{array}{c}-4.85 * * * \\
(9.64) \\
\end{array}$ & $\begin{array}{c}-6.39 * * * \\
(8.64) \\
\end{array}$ \\
\hline Private credit/GDP t-1 & & $\begin{array}{c}0.07 \\
(1.00)\end{array}$ \\
\hline Financial Repression t & & $\begin{array}{c}-40.73^{* * *} \\
(9.76) \\
\end{array}$ \\
\hline Institutional Quality & & $\begin{array}{c}15.01^{* * * *} \\
(7.72) \\
\end{array}$ \\
\hline No. of observations & 1712 & 1186 \\
\hline $\begin{array}{l}\text { Percent of liberalization } \\
\text { observations correctly predicted }\end{array}$ & 84.9 & 84.8 \\
\hline $\begin{array}{l}\text { Percent of capital control } \\
\text { observations correctly predicted }\end{array}$ & 19.4 & 57.1 \\
\hline Log likelihood & -1077.17 & -596.53 \\
\hline Pseudo-R2 & 0.4105 & 0.6232 \\
\hline
\end{tabular}

Notes: Z-statistics are reported in parentheses; ***, ** and * are significant at $1 \%, 5 \%$ and $10 \%$ level respectively; Threshold for correct predictions is $24.01 \%$, the unconditional frequency of capital account liberalization (i.e., ratio of number of country-years with capital account liberalization to total country-years with available data). 


\section{Appendix C. Currency Crisis and Capital Account Liberalization Episodes}

\begin{tabular}{|c|c|c|}
\hline Country & Currency Crisis Episodes & $\begin{array}{l}\text { Capital Account Liberalization } \\
\text { Episodes }\end{array}$ \\
\hline Argentina & 1975, 1982, 1989 & 1993- \\
\hline Bangladesh & 1975 & \\
\hline Belize & & 1981-85 \\
\hline Bolivia & 1981, 1983, 1988, 1991 & 1975-80, 1986-95 \\
\hline Botswana & 1984, 1996 & \\
\hline Brazil & 1982, 1987, 1990, 1995 & \\
\hline Burundi & 1976, 1983,1986, 1989, 1997 & \\
\hline Cameroon & 1982, 1984, 1994 & \\
\hline Chile & 1985 & \\
\hline China, P.R.: Hong Kong & & $1975-$ \\
\hline Colombia & 1985 & \\
\hline Costa Rica & 1981 & 1980-81, 1995- \\
\hline \multicolumn{3}{|l|}{ Cyprus } \\
\hline Dominican Republic & 1985, 1987, 1990 & \\
\hline Ecuador & 1982, 1985, 1988 & 1975-85, 1988-92, 1995 \\
\hline Egypt & 1979, 1989 & \\
\hline El Salvador & 1986, 1990 & $1996-$ \\
\hline Equatorial Guinea & 1991, 1994 & \\
\hline Ethiopia & 1992 & \\
\hline Fiji & 1986 & \\
\hline Ghana & 1978, 1983, 1986 & \\
\hline Grenada & 1978 & \\
\hline Guatemala & 1986, 1989 & 1975-79, 1989- \\
\hline Guinea-Bissau & 1991, 1996 & \\
\hline Guyana & 1987, 1989 & \\
\hline Haiti & 1977,1991 & \\
\hline Honduras & 1990 & 1975-79, 1993-95 \\
\hline Hungary & 1989, 1994 & \\
\hline India & 1976, 1991, 1995 & \\
\hline Indonesia & 1978, 1983, 1986, 1997 & $1975-95$ \\
\hline Jamaica & 1978, 1983, 1990 & $1996-$ \\
\hline Jordan & 1983, 1987, 1989, 1992 & \\
\hline Kenya & 1975, 1981, 1985, 1993, 1995, 1997 & 1996- \\
\hline Korea & 1980, 1997 & \\
\hline Lao People’s D. R. & 1995 & \\
\hline
\end{tabular}




\begin{tabular}{|c|c|c|}
\hline Madagascar & 1984, 1986, 1991, 1994 & \\
\hline Malawi & 1982, 1985, 1992, 1994 & \\
\hline Malaysia & 1986, 1997 & 1975-95 \\
\hline Mali & 1993 & \\
\hline Malta & 1992, 1997 & \\
\hline Mauritius & 1979 & $1996-$ \\
\hline Mexico & 1976, 1982, 1985, 1994 & $1975-81$ \\
\hline Morocco & 1983, 1990 & \\
\hline Mozambique & 1993, 1995 & \\
\hline Myanmar & 1975, 1977 & \\
\hline Nepal & 1975, 1981, 1984, 1991, 1995 & \\
\hline Nicaragua & 1993 & 1975-77, 1996- \\
\hline Nigeria & 1986, 1989, 1992 & \\
\hline \multicolumn{3}{|l|}{ Pakistan } \\
\hline Panama & & 1975- \\
\hline Paraguay & 1984, 1986, 1988, 1992 & 1982-83, 1996- \\
\hline Peru & 1976, 1979, 1987 & 1978-83, 1993- \\
\hline Philippines & 1983, 1986, 1997 & \\
\hline Romania & 1990 & \\
\hline Sierra Leone & 1988, 1990, 1997 & \\
\hline Singapore & 1975 & $1978-$ \\
\hline South Africa & 1975, 1978, 1984, 1996 & \\
\hline Sri Lanka & 1977 & \\
\hline Swaziland & 1975, 1979, 1982, 1984 & \\
\hline Syrian Arab Republic & 1977, 1982, 1988 & \\
\hline Thailand & 1981, 1984, 1997 & \\
\hline Trinidad \& Tobago & 1985, 1988, 1993 & $1994-$ \\
\hline Tunisia & 1993 & \\
\hline Turkey & 1978, 1994 & 1997- \\
\hline Uganda & 1981, 1987, 1989 & $1997-$ \\
\hline Uruguay & 1982 & 1978-92, 1996- \\
\hline Venezuela & 1984, 1986, 1989, 1994 & 1975-83, 1996- \\
\hline Zambia & 1985, 1994 & 1996- \\
\hline Zimbabwe & 1982, 1991, 1994, 1997 & \\
\hline
\end{tabular}

Notes: Currency crises defined by criteria described in text, with 24-month exclusion windows imposed. Blank cell indicates currency crisis never occurred or capital controls never implemented. 